\title{
Contribution to the Study of the European Ground Squirrel's Population (Spermophilus citellus Linnaeus, 1766) in Rila National Park, Bulgaria
}

\author{
Przyczynek do badań populacji susła moręgowanego (Spermophilus citellus Linnaeus, 1766) \\ w Parku Narodowym „Rila” (Bułgaria)
}

\author{
Emanuil Mitrevichin, Lidia Sakelarieva \\ Department of Geography, Ecology and Environmental Protection, South-West University "Neofit Rilski", Blagoevgrad, Bulgaria \\ ORCID: EM https://orcid.org/0000-0002-4497-7644; LS https://orcid.org/0000-0001-9779-3075• mitrevichin.emanuil@abv.bg \\ Received: 20 Aug 2020; Revised: 27 Nov 2020; Accepted: 10 Dec 2020
}

\begin{abstract}
Although there are still some large and stable populations of the European Ground Squirrel, there has been a serious decline in the number and density of most of the species populations throughout its range, including in Bulgaria. The aim of the study is to supplement the scientific data about the population of the European Ground Squirrel and its habitat in Rila National Park, Southwestern Bulgaria. The research was carried out in 2017-2019 in two study areas, each divided into 20 (21) transects (every $100 \mathrm{~m}$ long and $5 \mathrm{~m}$ wide). The results have shown that the relative population density based on the number of holes tends to decrease in the period of study. The most likely reason for this, and the most significant identified threat to the population of the species in the research area in general, is the observed deterioration of the habitat status.
\end{abstract}

Keywords: monitoring, population density, habitat parameters, Spermophilus citellus, Rila National Park

Streszczenie: Pomimo tego, że na całym obszarze występowania susła moręgowanego, również w Bułgarii, znajdują się nadal duże i stabilne populacje tego gatunku, to aktualnie obserwuje się poważny spadek liczebności i zagęszczenia większości jego populacji. Celem badań było uzupełnienie danych na temat stanu populacji susła moręgowanego i jego siedlisk w Parku Narodowym "Rila", w południowo-zachodniej Bułgarii. Badania zostały przeprowadzone w latach 20172019 na dwóch obszarach badawczych. Każdy z nich był podzielony na 20 (21) transektów 0 długości 100 m i szerokości 5 m. Stwierdzono, że w okresie badań, względne zagęszczenie populacji susła mierzone liczbę nor wykazywało tendencję spadkową. Wskazano na pogorszenie się stanu siedlisk jako najbardziej prawdopodobną przyczynę tego zjawiska oraz jako najbardziej istotne zagrożenie dla populacji gatunku na obszarze badań.

Słowa kluczowe: monitoring, zagęszczenie populacji, warunki siedliskowe, Spermophilus citellus, Park Narodowy „Rila” 


\section{Introduction}

The European Ground Squirrel (Spermophilus citellus Linnaeus, 1766) is endemic to Central and Southeastern Europe, and its habitat is divided into two parts by the Carpathian Mountains (Попов 2007, 169; Janák et al. 2013, 4, 12). In Bulgaria, the species can be spotted throughout the country, except for some areas in the south-western part of the country where the species is no longer found. It occurs from the sea level to the altitude of $2600 \mathrm{~m}$ (Попов и Седефчев 2003, 134; Peshev, Peshev, and Popov 2004, 317; Попов 2007, 170; Koshev 2008, 254-255; Кошев 2015, 629; Кошев 2018, 24-25).

A unique population of the European Ground Squirrel occurs in the Rila Mts. Being completely isolated from other populations of the species in the country, it is characterized by a subspecies specificity Spermophilus citellus martinoi Peshev, 1955 with a unique chromosomal characteristics (Chassovnikarova et al. 2015, 366-371). The range of this population is divided into two parts, one located within the boundaries of Rila National Park, and the other outside its boundaries and therefore deprived of any protection. The first one is situated at $2500-$ $2600 \mathrm{~m}$ above the sea level, which makes it the highest point in the whole range of the species (Кошев 2015, 629-639; Кошев 2018, 31).

The pioneering studies of the species in the Rila Mts were realized in the middle of the last century. Later, in 2002-2003, a monitoring was carried out. Regular surveys of a diverse nature were launched in 2005. Three years later, according to the methodology established by the Ministry of Environment and Water, regular monitoring of the European Ground Squirrel within the National Biodiversity Monitoring System began. The analysis and generalization of the information accumulated in the period 2003-2015 indicates that species abundance is gradually declining (Кошев 2015, 626-631).

Recently, the status of the species in Bulgaria, but also in its entire range, has deteriorated, that is why it is included in some Bulgarian and international documents in the field of biodiversity conservation. Such documents are Appendix II of the Biodiversity Protection Act of Bulgaria, the Red Data Book of the Republic of Bulgaria (Stefanov 2015) category Vulnerable, the IUCN Red List of Threatened Species category Endangered, Annexex II and IV of the Directive 92/43/EC, Appendix II of the Bern Convention (Попов 2007, 174; Koshev 2008, 259; Janák et al. 2013, 24; Кошев 2018, 8-11; Hegyeli 2020).

The aim of the present study is to supplement the scientific data about the population and the habitat of the European Ground Squirrel in the park section of Belovo, Rila National Park.

\section{Material and methods}

The population of the species in Belovo Park Section of Rila National Park, Southwestern Bulgaria was studied in the period 20172019. The field observations were conducted together with an expert from the directorate of Rila National Park on September 19 and 20,2019 . The same expert has provided data from the monitoring held in the previous two years, on September 14 and 15, 2017, and on October 11 and 12, 2018. The monitoring was carried out in 2 study areas, according to the methodology approved by an order of the Minister of Environment and Water for monitoring the European Ground Squirrel (Кошев и Ap. 2015). Each study area was divided into 20 transects (except for 2018, when one additional transect was added to study area 1): every $100 \mathrm{~m}$ long and 5 $\mathrm{m}$ wide. The two study areas were located next to each other on a terrain with one and the same altitude, inclination and exposure (southern).

The monitoring parameters included: number of the species' holes (an indirect indicator for the relative population density), number of active animals, number of alarm calls, and some habitat parameters as habitat type, high-stem vegetation cover degree, grass cover degree, grass cover height, total mowing/grazing cover, mowing/grazing 
intensity. In 2017, the habitat parameters were not assessed. The threats to the population of the species such as: plowing and/or land-use change of grassland habitats, habitat burning, use of rodenticides, pesticides, and other substances toxic to mammals in the habitat or others have also been registered (Костова и Ар. 2015, 1-4).

The condition of the species habitat parameters has been assessed as favorable, unfavorable-unsatisfactory or unfavorablebad in accordance with their values (Table 1).

Technical equipment such as GPS, field form, binoculars, tape measure, and radio stations was used during the field studies (Кошев и Ар. 2015, 7).

\section{Results}

\subsection{Population parameters}

\subsubsection{Relative population density of the European ground squirrel on the territory of Belovo Park Section - number of holes.}

The number of holes in study area 1 varied between 95 and 128. In 2017 it was 117, then in 2018 there was an increase in the number of holes to 128 , and this number does not include the holes counted within the additional transect 21, which were 45 . However, in 2019 a decrease to 95 holes was registered (Fig. 1).

The number of holes in study area 2 ranges from 110 to 139 . It was the largest in $2017-$ 139 , then decreased to 119 in 2018 , reaching its lowest value of 110 in 2019 (Fig. 1).

The total number of holes counted in the whole study area in each year was different. The highest number of holes was registered in $2017-256$, and the lowest in 2019 (Fig. 1).

The number of holes per transect in the two study areas varied widely in different years. For study area 1 , the minimum number of holes within a transect was o in 2017 and 2018, and 1 in 2019, while the maximum number was 18 in 2017, 32 in 2018 (45 within the additional transect), and 29 in 2019 (Fig. 2). During the study period, most holes were counted within transects $1,8,10$, and 20 (for $2018-21$ ).

The minimum number of holes registered within a transect in study area 2 was 1 in 2017 , $\mathrm{o}$ in 2018, and 2 in 2019, and the maximum one -21 in 2017,16 in 2018 , and 11 in 2019 (Fig. 3). The transects with a relatively large number of holes were $5,14,16,17$, and 18 (Fig. 3).

Table 1. Habitat parameters and threshold values that determine their condition (FC - favorable condition, UUC - unfavorable-unsatisfactory condition, UBC - unfavorable-bad condition) (Костова и Aр. 2015, 2-3)

\begin{tabular}{|c|c|c|c|}
\hline Parameter & $\begin{array}{l}\text { Values that determine } \\
\text { FC }\end{array}$ & $\begin{array}{l}\text { Values that determine } \\
\text { UUC }\end{array}$ & $\begin{array}{l}\text { Values that determine } \\
\text { UBC }\end{array}$ \\
\hline Habitat type & $\begin{array}{l}\text { Pasture: } \geq 90 \% \\
\text { Meadow: } \geq 5 \%\end{array}$ & $\begin{array}{l}\text { Pasture: between } 85-90 \% \text {; Meadow: } \\
\qquad 4-5 \%\end{array}$ & $\begin{array}{l}\text { Pasture: }<85 \% \\
\text { Meadow: }<4 \%\end{array}$ \\
\hline $\begin{array}{l}\text { High-stem } \\
\text { vegetation cover } \\
\text { degree }\end{array}$ & Overgrowth (0-5\%): $\geq 87 \%$ & $\begin{array}{l}\text { Overgrowth }(0-5 \%) \text { : } \\
\text { between } 85-87 \%\end{array}$ & $\begin{array}{l}\text { Overgrowth }(0-5 \%): \\
\quad<85 \%\end{array}$ \\
\hline Grass cover degree & (Over $76 \%): \geq 90 \%$ & (Over $76 \%$ ): between $80-89 \%$ & $($ Over $76 \%):<80 \%$ \\
\hline Grass cover height & $\begin{array}{c}(0-15 \mathrm{~cm}): \geq 60 \% \\
(16-30 \mathrm{~cm}): \text { between } 25-30 \%\end{array}$ & $\begin{array}{l}(0-15 \mathrm{~cm}) \text { : between } 55-59 \% \text {; } \\
(16-30 \mathrm{~cm}) \text { : between } 20-24 \% \\
\text { or } \geq 31 \%\end{array}$ & $\begin{array}{l}(0-15 \mathrm{~cm}):<55 \% \\
(16-30 \mathrm{~cm}):<20 \%\end{array}$ \\
\hline $\begin{array}{l}\text { Total mowing/ } \\
\text { grazing cover }\end{array}$ & $\begin{array}{l}(51-80 \%): \geq 30 \% \\
(\text { Over } 81 \%): \geq 60 \%\end{array}$ & $\begin{array}{c}\text { (51-80\%): between } 25-29 \% \text {; (Over } \\
81 \%) \text { : between } 55-59 \%\end{array}$ & $\begin{array}{l}(51-80 \%):<25 \% \\
(\text { Over } 81 \%):<55 \%\end{array}$ \\
\hline $\begin{array}{l}\text { Mowing/grazing } \\
\text { intensity }\end{array}$ & $\begin{array}{l}\text { Well grazed/mowed: } \\
\quad \geq 70 \%\end{array}$ & $\begin{array}{l}\text { Well grazed/mowed: } \\
\text { between } 65-69 \%\end{array}$ & $\begin{array}{l}\text { Well grazed/mowed: } \\
<65 \%\end{array}$ \\
\hline
\end{tabular}




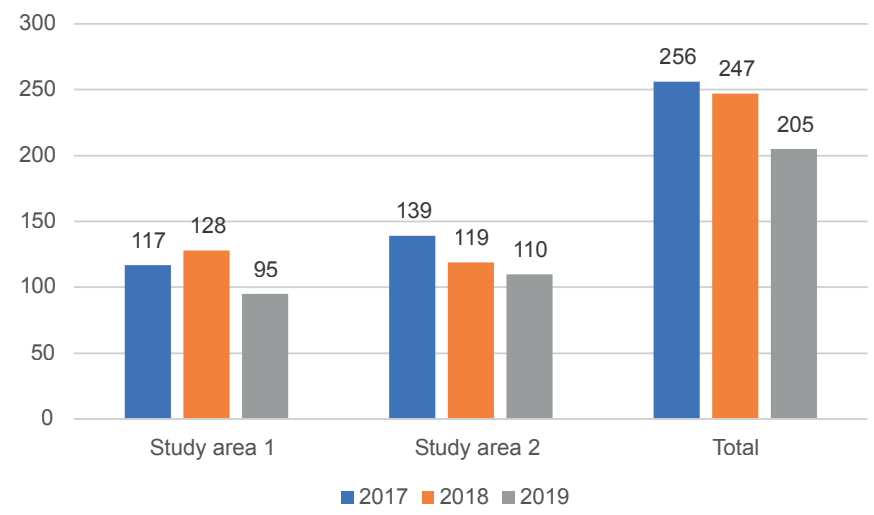

Figure 1. Number of holes registered in the study areas and the whole study area in 2017-2019

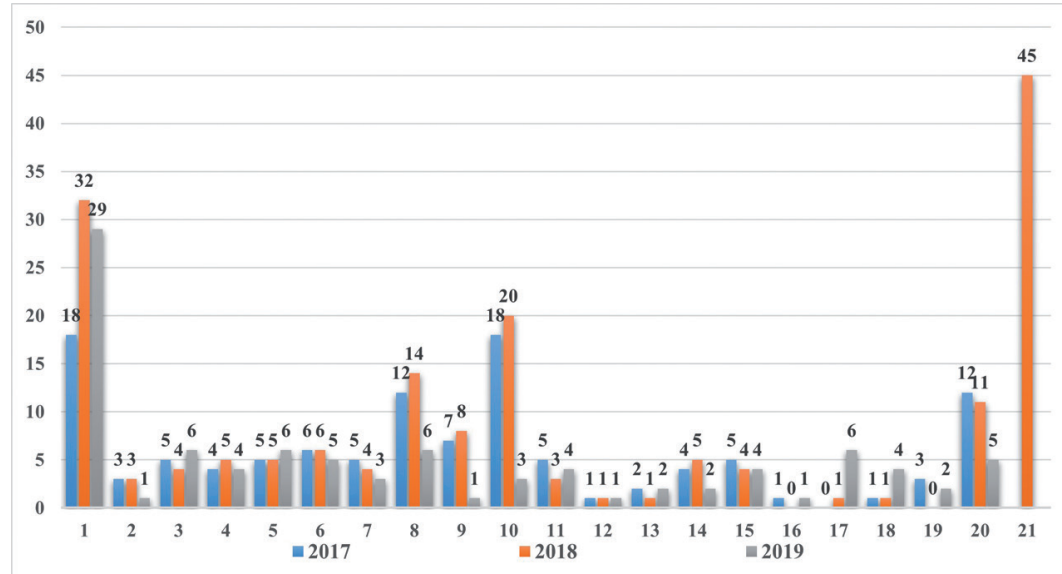

Figure 2. Number of holes within each transect on study area 1 during the study period

25

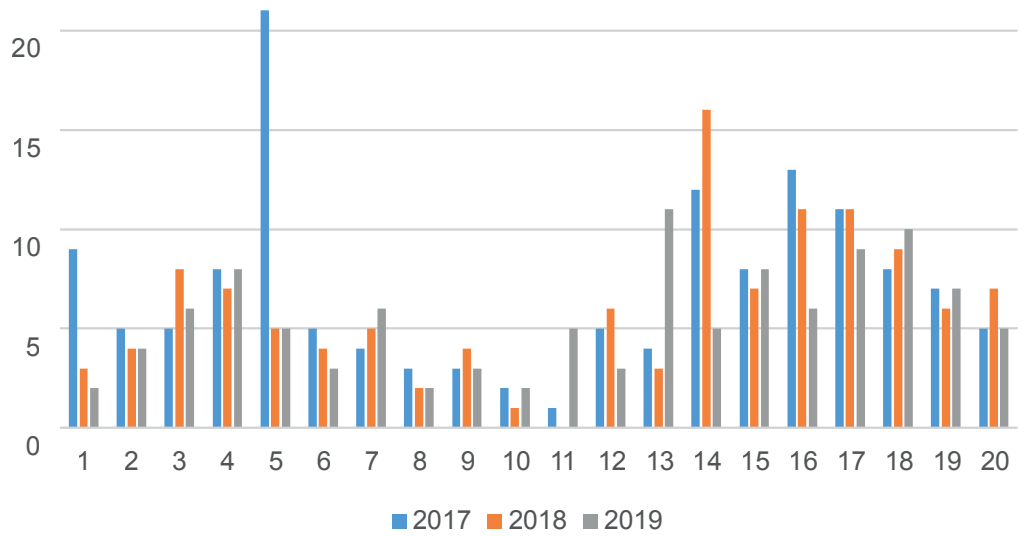

Figure 3. Number of holes within each transect on study area 2 during the study period 
The average number of holes in an area of $0,05 \mathrm{~h}$ (per transect) in study area 1 varied from 4.75 to 6.4 (or to 8.2 if the holes counted within transect 21 are included). It was 5.85 in $2017,6.4$ in 2018 , and only 4.75 in 2019. The average number of holes per transect in study area 2 wa s 6.95 in $2017,5.95$ in 2018 , and 5.5 in 2019.

The average number of holes in an area of $0,05 \mathrm{~h}$ in the whole study area was 6.4 in 2017, 6.18 in 2018 (or 7.12 if the holes within transect 21 are included), and 5.13 in 2019. For the whole period of study $(2017-2019)$ this number was 5.9 (or 6.2 if the holes counted within transect 21 are included).

The holes distribution within the two areas was different. Unlike study area 1, the holes of the species in study area 2 were generally evenly distributed.

\subsubsection{Number of active animals and alarm calls}

The total number of active individuals observed in study area 1 during the period of study was 10: 4 in 2017 and 2018, and 2 in 2019. Most of the animals were observed within transects $1,8,20$, and 21 in which the most or close to the maximum number of holes were registered (Photo. 1).

The total number of active specimens observed in study area 2 was 6: 4 in 2017, and 1 in 2018 and 2019. The majority of specimens (five out of six or $83.33 \%$ ) were registered within transect 1 . One specimen was observed within transect 5 .

The total number of alarm calls registered during the whole period of study was only 7 .

\subsection{Habitat status during the study period}

European Ground Squirrels used pastures as their habitat in both study areas. An analysis of the data for study area 1 in 2018 shows that five of the six habitat parameters are in favorable condition. Only the parameter High-stem vegetation cover degree, was in unfavorable-bad condition (Table 2). The analysis of the information for the same study area, but a year later shows a very strong deterioration of the parameters of the habitat. Only the habitat type parameter is in favorable condition. The parameter Grass cover degree was in unfavorableunsatisfactory condition and all the other parameters are in unfavorable-bad condition (Table 2).

The analysis of the data for study area 2 in 2018 indicates that half of the parameters are in favorable condition, one is in unfavorableunsatisfactory and two - in unfavorable-bad condition (Table 2).

The analysis of the information for the same study area, but a year later shows that the condition of four parameters remains the same, and the other two are worsened (Table 2).

\subsection{Threats to the species in the research area}

The identified threats to the population of the species in the territory of Belovo Park Section during the study period are:

- The low intensity of mowing and grazing within the two study areas;

- The presence of a small parking lot and a road, which are located next to the habitat of the species;

- A possible threat to animals is posed by shooting sports athletes staying at the Belmeken High Mountain Sports Complex.

\section{Discussion}

The main reason for the change in the number of the species' holes observed in the research area during the study period is the alteration in the condition of its habitat, which has been previously described by other authors for the same area (Кошев 2015, 633-666). The species habitat condition correlates directly with the status of its populations, which determines the number of holes within its boundaries. The European Ground Squirrel inhabits mainly open places, which are strongly dominated by grass species, and the high-stem vegetation is poorly represented (Peshev, Peshev, and Popov 2004, 317; Попов 2007, 170; Koshev 2014, 111-112; Nedyalkov and Koshev 2014, 208; Ramos-Lara et al. 2014, 77). The reduction in the number of holes in 2019 is associated with a particularly high degree 


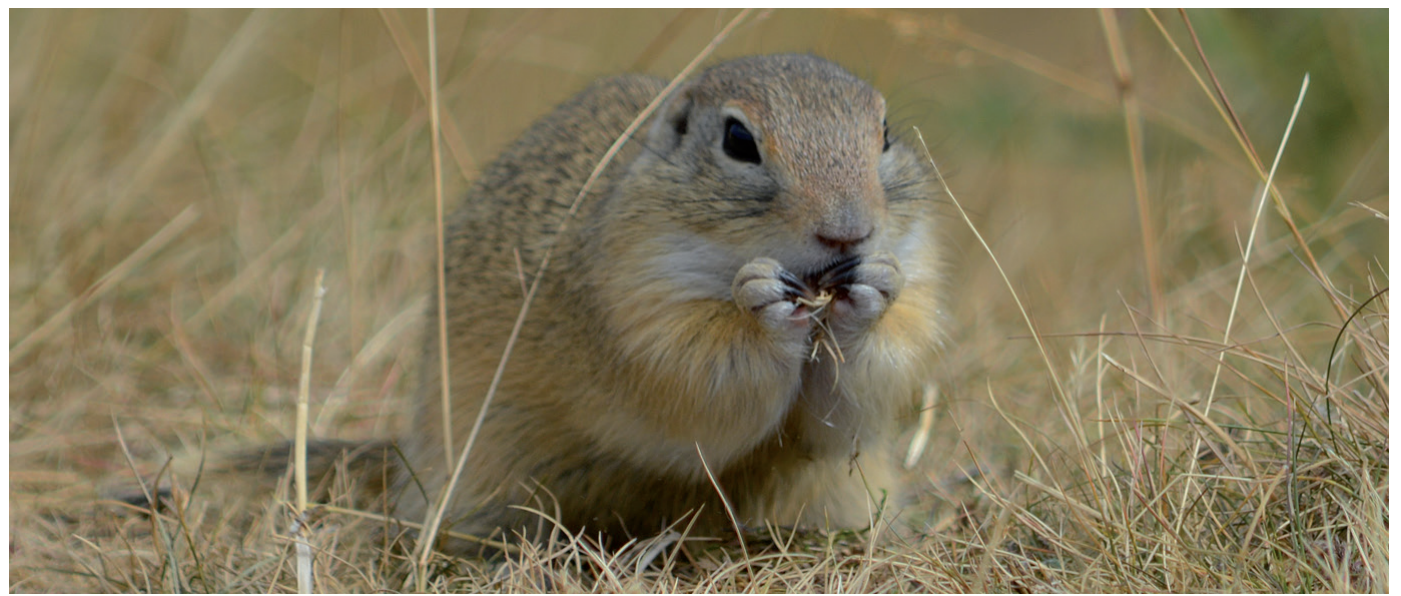

Photograph 1. European Ground Squirrel registered during the field observations (transect 1, study area 1). (photograph by Emanuil Mitrevichin)

Table 2. Condition of the habitat parameters

\begin{tabular}{lcccc}
\hline & \multicolumn{2}{c}{ Study area 1 } & \multicolumn{2}{c}{ Study area 2 } \\
\hline Habitat parameters & 2018 & 2019 & 2018 & 2019 \\
\hline Habitat type & FC & FC & FC & FC \\
\hline High-stem vegetation cover degree & UBC & UBC & UBC & UBC \\
\hline Grass cover degree & FC & UUC & UUC & UUC \\
\hline Grass cover height & FC & UBC & FC & UBC \\
\hline Total mowing/grazing cover & FC & UBC & FC & UUC \\
\hline Mowing/grazing intensity & FC & UBC & UBC & UBC \\
\hline
\end{tabular}

of habitat degradation. This is probably due to the fact that the shepherds have brought their flocks to grazing within the study area much less often than in the previous two years.

The larger total number of holes recorded in 2017 and 2018 can be explained by the relatively better living condition in the species habitat in these years than in 2019 A survey conducted in 2008 showed that the total number of holes of the species was 316 , which is quite a difference compared to the registered total number of holes in 2017 , 2018, and especially in 2019 (35\% less than in 2008) (Fig. 1) (Кошев 2015, 631-632).

The fact that most of the species holes were mainly in the range of transects $1,8,10,20$, and 21 (study area 1) can be partly explained by the location of some of these transects. Transects 1, 20, and 21 are situated at the lowest altitude and the smallest terrain slope. Probably, the meteorological conditions in this part are more suitable for the animals (higher air and soil temperature, lower wind speed, etc.). Furthermore, the smaller slope of the terrain facilitates animals' movement.

However, the second most preferred part of the habitat of the species, where individuals dig their holes, is at its edges (transects 8 and 10) at a higher altitude and in more unfavorable meteorological conditions. This shows that despite the tendency of individuals to concentrate mainly in the areas of the habitat that are characterized by more favorable meteorological conditions and less terrain slope, they are still well enough adapted to the harsher and extreme environmental conditions. This also indicates that the greater terrain slope does 
not appear to be an insurmountable barrier to the spread of the specimens.

The different pattern of holes distribution shows that the terrain slope and altitude are not necessarily the most important environmental factors influencing the choice of the animals in which parts of the habitat to dig their holes. This ascertainment suggests that there should also be other potential limiting factors that affect this activity namely the habitat parameters in the two study areas. Even within each of the two study areas in some sections, the values of the parameters often differ to a great extent. For example, Grass cover degree for a certain transect can be over $70 \%$, and for another transect in the same study area - from o to $25 \%$. The animals would probably prefer to dig and arrange their holes predominantly within transects, which are characterized by more favorable parameter values.

The decrease in the average number of holes per transect observed in the period of study is most likely due to the deteriorated condition of the habitat. Similar decrease in the relative density of the species was also registered during the monitoring carried out in 2008, 2011, and 2013 (Кошев 2015, 631632). However, long-term research is needed to establish whether this is a lasting trend.

The total number of observed active individuals during the study period in both study areas is quite small. Several reasons can be suggested here. The activity of the animals on the surface is determined by many factors such as climatic conditions, the presence of humans and predators, the period of monitoring implementation. Furthermore, the team focused their's attention during the monitoring mainly on the detection of holes of the species, which made it difficult for them to observe active animals simultaneously (Зидарова 2011, 7). The time of the year in which the animals return to their shelters and go into hibernation takes place in August-October (Попов 2007, 172; Ramos-Lara et al. 2014, 81; Haley and Mcgregor 2020), which coincides with the time the present study of the species was carried out. This reduces the chances of observing active animals, since many of them had already gone into hibernation. This can also explain the relatively small number of alarm calls registered during the study period.

A study conducted in the period 2003 2015 on the dynamics of the population abundance of the species in the area of Belmeken Dam found that it is gradually declining (Кошев 2015, 630-631). The results of the present study are similar and confirm the trend observed in that study.

The rapid degradation of the habitat in 2019 was probably caused by the fact that the local and non-local shepherds did not bring their flocks to grazing within its boundaries. Habitat parameters are interrelated. For example, if the total mowing/grazing cover for the respective year is not sufficient and the mowing/grazing intensity is not satisfactory, then the grass cover height will also be affected. It should also be noted that the grass cover height is also influenced by the climate characteristics in the respective year (Кошев и Ар. 2015, 5). In the last 30-40 years in Bulgaria, there has been a progressive abandonment of extensive livestock farming and mowing of pastures and meadows, which has a negative impact on the habitats of the species (Кошев 2018, 32-33). In case of a shortage of grazing animals and mowing within the habitats of the species, successional processes begin. This, in turn, leads to an increase in the grass vegetation, an increase in the percentage of the shrub species, and therefore to a deterioration in the habitat quality (Кошев 2018, 54).

The rapidly occurring negative changes in the habitat of the species in the absence or insufficient amount of grazing and mowing within its boundaries indicate that it is to some extent dependent on appropriate human intervention in its habitats.

The negative impact of the small parking lot and the road which are located near the habitat of the species is related to the passing cars, which can cause direct death 
of individuals. Furthermore, the noise they emit causes discomfort, anxiety, and stress to the animals (Кошев 2018, 59).

The sport shooting athletes pose a potential threat to the animals. In the second half of the $2 \mathrm{O}^{\text {th }}$ century, the ground squirrels were shot as living targets. There is currently no information on the existence of such an illegal practice, but the threat of similar unethical actions remains (Кошев 2018, 58-59).

\section{Bibliography}

Chassovnikarova, Tsenka, Michail Rovatsos, Nasko Atanasov, and Yordan Koshev. 2015. "Sex chromosome variability of Spermophilus citellus (Linnaeus, 1766) in the Southeastern part of the Balkan Peninsula." Mammalian Biology 80(4): 365-371. https://doi.org/10.1016/j. mambio.2014.10.002.

Haley, Jason, and Cari Mcgregor. "Spermophilus citellus.” Accessed September 21, 2020. https://animaldiversity.org/accounts/ Spermophilus_citellus/.

Hegyeli, Zsolt. 2020. “Spermophilus citellus." In The IUCN Red List of Threatened Species 2020: e.T20472A91282380. https://dx.doi.org/10.2305/ IUCN.UK.2020-2.RLTS.T20472A91282380.en. Accessed September 21, 2020.

Janák, Milan, Pavel Marhoul, and Jan Matějů. 2013. Action Plan for the Conservation of the European Ground Squirrel Spermophilus citellus in the European Union. Brussels: European Commission. Koshev, Yordan. 2008. "Distribution and status of the European Ground Squirrel (Spermophilus citellus) in Bulgaria." Lynx (Praha) 39(2): 251-261.

Koshev, Yordan. 2014. "Small Mammals (Mammalia: Erinaceomorpha, Soricomorpha, Rodentia and Lagomorpha) in Ponor Special Protection Area (Natura 2000), Western Bulgaria: Species Diversity, Distribution and Conservation." Acta Zoologica Bulgarica Suppl. 5: 107-115.

Nedyalkov, Nedko, and Yordan Koshev. 2014. "Small Mammals (Erinaceomorpha, Soricomorpha, Rodentia, Lagomorpha) in Besaparski Ridove Special Protection Area (Natura 2000), Southern Bulgaria: Species Composition, Distribution and Conservation." Acta Zoologica Bulgarica Suppl. 5: 201-212.
Peshev, Tsolo, Danielo Peshev, and Vasil Valkov Popov. 2004. Fauna of Bulgaria: Mammalia. Sofia: Marin Drinov.

Ramos-Lara, Nicolás, John L. Koprowski, Boris Kryštufek, and Ilse E. Hoffmann. 2014. "Spermophilus citellus (Rodentia: Sciuridae).“ Mammalian Species 46(913): 71-87. https://doi. org/10.1644/913.1.

Stefanov, Vladimir. 2015. European ground squirrel (Spermophilus citellus Linnaeus, 1766). In Red Data Book of the Republic of Bulgaria (Part 2) Animals, edited by Vasil Golemansky, and Dimitar R. Peev, 232. Sofia: BAS \& MOEW. http://e-ecodb. bas.bg/rdb/en/vol2/Spcitell.html.

Зидарова, Сирма. 2011. „АокмаА по Аоговор № 1960/13.04.2011 г. по проект BG0052 'Развитие на информационна система към националната система за мониторинг на биологичното разнообразие в Бъцгария'” Accessed August 9, 2020. http://eea.government.bg/bg/bio/ nsmbr/reports. [Zidarova, Sirma. 2011. „Doklad po dogovor № 1960/13.04.2011 g. po proekt BG0052 'Razvitie na informatsionna Sistema kam natsionalnata sistema za monitoring na biologichnoto raznoobrazie v Bulgaria.'”]

Костова, Румяна, Надя Цветкова и Йордан Кошев. 2015. Методика за оценка състоянието на Европейски лалугер (Spremophilus citellus L. 1766). София: ИАОС http://eea.government. bg/bg/bio/opos/activities-results/Metodika_za_ ocenka_Spermophilus_citellus.pdf/view [Kostova, Rumyana, Nadya Tsvetkova i Yordan Koshev. 2015. Metodika za otsenka sastoyanieto na Evropeyski laluger (Spermophilus citellus L. 1766). Sofia: IAOS].

Кошев, Йордан, НаАя Цветкова, и Румяна Костова. 2015. Методика за мониторинг на Европейски макугер (Spermophilus citellus L. 1766). София: ИАОС. http://eea.government.bg/bg/bio/ nsmbr/praktichesko-rakovodstvo-metodiki-zamonitoring-i-otsenka/Metodika_za_ocenka_ Spermophilus_citellus.pdf [Koshev, Yordan, Nadya Tsvetkova i Rumyana Kostova. 2015. Metodika za monitoring na Evropeyski laluger (Spermophilus citellus L. 1766). Sofia: IAOS].

Кошев, Йордан. 2015. “Европейски махугер (Spermophilus citellus).” В Проект на план за управление на Национален парк „Рима“, 20152024 г. Сборник биологична характеристика 
- том 2, 626-642. София: А33А „Рима Консултанти.” [Koshev, Yordan. 2015. "Evropeyski laluger (Spermophilus citellus)." V: Proekt na plan za upravlenie na Natsionalen park "Rila", 20152024 g. Sbornik biologichna harakteristika - tom 2, 626-642. Sofia: DZZD “Rila Konsultanti.”].

Кошев, Йордан. 2018. План за действие за опазване на европейския макугер (Spermophilus citellus) в Бъмгария: 2018-2027. София: МОСВ, БАЗП. https://www.moew.government.bg/static/ media/ups/tiny/filebase/Nature/Biodiversity/ NCBP/NSBR2018/BDZPRilaBufer/Action_plan_S_ citellus_Bulgaria_MOEW_20180328.pdf. [Koshev, Yordan. 2018. Plan za deystvie za opazvane na evropeyskia laluger (Spermophilus citellus) v Bulgaria: 2018-2027. Sofia: MOSV, BDZP].

Микушев, ВАадимир. 2012. Наръчник за работа с доброволии при провеждане на дейности по наблюдение на процеса на възстановяване и аклиматизация на европейския лалугер на територията на Природен парк „Витоша“. София: Природен парк „Витоша“. [Milushev,
Vladimir. 2012. Narachnikza rabota s dobrovoltsi pri provezhdane na deynosti po nablyudenie na protsesa na vazstanovyavane i aklimatizatsia na evropeyskia laluger na teritoriyata na Priroden park "Vitosha". Sofia: Priroden park "Vitosha"].

Попов, Васиц, и Атила Седефчев. 2003. Бозайниците в Бъмгария. ОпреАелител. София: Природен парк „Витоша“. [Popov, Vasil, i Atila Sedefchev. 2003. Bozaynitsite v Bulgaria. Opredelitel. Sofia: Priroden park "Vitosha"].

Попов, Васим. 2007. „Аамугер (Spermophilus citellus Linaeus, 1766)." В Бозайниците, важни за опазване в Бъцгария, РеА. Васил Попов, Николай Спасов, Теодора Иванова, Боряна Михова и Кирил Георгиев, 169-174. Arnhem: Dutch Mammal Society VZZ. [Popov, Vasil. 2007. „European souslik (Spermophilus citellus Linaeus, 1766)." In Bozaynitsi, vazhni za opazvane v Bulgaria, red. Vasil Popov, Nikolay Spasov, Teodora Ivanova, Boryana Mihova, i Kiril Georgiev, 169-174. Arnhem: Dutch Mammal Society]. 